JAPANESE JOURNAL OF INFLAMMATION EDITORIAL

Affection for mucous membrane immunology

Katsuo Kumagai*

\title{
粘膜免疫学への思い入れ
}

\section{熊谷勝 男*}

私は平成 7 年に停年で東北大学を退官して, 平成 8 年に新しい試験的研究体勢に入 り，1昨年(平成 9 年 2 月 3 日) から現在の研究所で所長として働いている.

農水省の生研機構の出資を中心につくられた株式会社であり, 研究所名は私自身の 命名によるティーセル $(T-$ cell) 研究所である. 研究課題は, 日本の乳用牛の最大の病気 の一つ, 乳房炎を中心とした乳牛などの難治性疾患の新療法の開発である.今日まで, 2 年 7 力月経たことになる. 現在, 日本には乳用牛は育成牛を含めて, 200 万頭の多く が飼養されている。しかし，この1/5 は多かれ少なかれ多種類の細菌感染による乳房 炎に悩まされている計算となり，世界的にもほとんど同様であり，その世界的経済的 損失は計り知れないものがある。

人間で学んできた細菌学や免疫学のアプローチを生かして，この家畜の難治性感染 症の防除に挑戦となったものである。本日は，その成果について記すのが目的ではな く, この研究を進めるに当たって必要な, 乳腺という乳汁分泌臓器の特異性, 特に, その免疫学的特異性にふれて，ホルモンに依存した粘膜免疫臓器というもののすごさ を紹介してみたくなったのである.

私は, 免疫学を総論的に考究してはきたが，これを特定の臓器から各論的に近寄っ たことがない。乳腺臓器をいじることではじめてその経験を得た。それも人間ではな く, 巨大な乳牛の乳腺である。 ウシの乳腺は左右前後に 4 分房あって, 飼育されてい る成牛 1 頭から, 通常 1 日で 20〜30 リットルの乳汁が採取できる。いわば， 1 頭が年 間 10 トン以上ものミルクを生産する工場みたいなものである.

研究をはじめるに当たっては，まず，この乳汁中の免疫担当細胞の実体を知ること を志した，実際的には，各泌乳牛の乳頭口から，4〜5リットルの新鮮な乳汁を採取 して, 遠心で細胞を集めて, 蛍光抗体法でそのリンパ球(特に, Tリンパ球)のサブセッ トの同定を行った。そこで，まず驚いた。圧倒的に $\mathrm{CD} 8^{+} \alpha \beta \mathrm{T}$ と $\mathrm{CD} 4^{-} 8^{-} \gamma \delta^{+} \mathrm{T}$ 細胞 の多いことであった。その特徵は, ヒトでも他のマウスなどの実験動物でも，腸管の 上皮内 Tリンパ(IEL)のそれに一致する構成であった。つまり，ミルクのリンパ球は圧

* T-Cell Research Institute (株ティーセル研究所, 東北大学名誉教授 
倒的に腸管などの粘膜上皮内 Tリンパ球と類似の構成細胞からなっているということ を知ったのである。実際は, 今さら驚くほどのことはなく, ほとんどの動物 (ヒトも含 めて)の乳腺内リンパ球は, ウシの場合と同じで,いわば腸管の IEL と同様の構成から なっていることは近年わかっていたのである。

そして，実際は，この IEL はミルクを遠心して集めると，事もなく手中にできると いうことである。したがって，まず，ミルクは粘膜免疫Tリンパ球のたぐいまれな研 究材料であると感嘆したのであった。われわれの研究で，もっと驚くことがすぐにわ かったのである。それは乳牛は子を分婏して泌乳活動に入るが，泌乳期のかなり早い 時期に人工授精で交配しており，ミルクの採取を行っている間に，妊娠子宮内では胎 児が生長していき, 時が来れば, 泌乳活動は減弱し, 出産が迫るから乳房からの搾乳 を中止する. 当然, 乳腺上皮はアポトーシスで消失し, その乳汁分泌は止み, 乳腺に は血行やリンパ行由来のリンパ球の集まる期間となる(これを乾乳期という)。その分 泌液のTリンパ球を調べたら,これがほとんど血液と似た $\mathrm{CD} 4^{+} \alpha \beta \mathrm{T}$ 優先の構成に変 わり，乳腺中から $\mathrm{CD} 8^{+} \mathrm{T} や \gamma \delta^{+} \mathrm{T}$ 細胞が見事に消失している。 つまり，上皮内 $\mathrm{T} リ$ ンパ球(IEL) は, 消えているのである.つまり, 乳腺では, その泌乳サイクルに応じて, その分泌液中の Tリンパ球は胸腺外 T 細胞である IEL から胸腺依存性 T 細胞にあっ という間に変わるということである.

IEL の研究臓器の一つである腸管ではその動物の生まれてから死ぬまで, 腸管上皮 がなくなるなどということはない. したがって，同一の臓器内で，こんな旧世代のT 細胞集団から新世代のT細胞への交代が眼前に展開するなどということはない．ホル モン依存性の臓器のなんという自然の妙，生体の妙であろうと感心してしまった。し

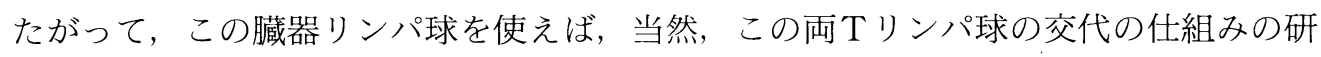
究も可能であるし, IEL を入手して, 胸腺外 Tリンパ球の性状, 機能, 分化そのもの の追求も可能である. しかも，このリンパ球は，ミルクを採取することによって，い つでも手に入れることが可能である.

粘膜免疫の研究をしたければ，山ほどそのテーマは存在する。とりあえず，われわ

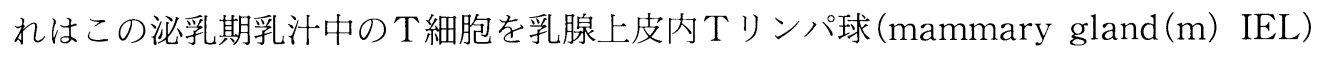
と命名して，常識的に ConA や PHA への反応性を調べてみた。その結果，これらの $\gamma \delta \mathrm{T}, \mathrm{CD} 8^{+} \mathrm{T}$ が主体の mIEL はいずれにも増殖反応は示さず，サイトカイン (IL-2, IL-4)の産生はみられない.これに反して, 乾乳期に導入された CD $4^{+} \mathrm{T}$ 主体の乳腺分 泌液中のTリンパ球は, ばんばん反応して IL-2, IL-4をたくさん産生した。このこと は, さし当たって両期乳腺の免疫応答の違いを示唆し, 実際にTリンパ球構成の他, 乾乳期はヘルパーT依存性の抗体産生反応も旺盛, 顆粒球による食菌反応も盛んで, $\mathrm{CD} 8^{+} \mathrm{T}, \gamma \delta \mathrm{T}$ 主体の泌乳期の免疫組織と大違いである。（この間の成績については, 
本研究所と共同研究者の東北大学農学部山口高弘助教授との 2 論文を末尾に引用して ある). 当然のことながら, これらの泌乳期, 乾乳期の乳腺の感染防御機能は全く違う と考えてよいのではないかと思われる.

われわれの研究目的からいえば, このような乳腺リンパ球の研究は, 泌乳期, 乾乳 期両期で乳房炎防除の対策には天と地ほどの違いがあってもおかしくないことを示唆 している。つまりわれわれは，少なくとも，ホルモン依存性のこの両期の粘膜藏器で の乳房炎に対する防除対策には，これらの両期の免疫学的な違いを考慮に入れなけれ ばならないことを強く示唆した。

乳房炎防除対策の実際の研究はこれからであるが，われわれは，今，その免疫機構 の多彩さを示しながら，実際にこの機構を容易に解析できる乳腺のリンパ球組織に脱 帽しているところである.

1) Asai K, Kai K, Rikiishi H, Sugawara S, Maruyama Y, Yamaguchi T, Ohta M, Kumagai K : Variation in $\mathrm{CD} 4^{+} \mathrm{T}$ and $\mathrm{CD} 8^{+} \mathrm{T}$ lymphocyte subpopulations in bovine mammary gland secretions during lactating and non-lactating periods. Vet Immunol Immunopathol 65:51-61, 1998.

2) Yamaguchi T, Hiratsuka M, Kai K, Asai K, Kumagai K : Differential distribution of T lymphocyte subpopulations in the bovine mammary gland during lactaion. J Dairy Sci $82: 1459-1464,1999$. 